\title{
Conduct Radio Frequencies with Inks
}

\author{
Rudie Oldenzijl, Gregory Gaitens and Douglass Dixon \\ Henkel Corporation \\ United States
}

\section{Introduction}

The objective of this chapter is to give additional insight into the inks which are being used for printing RFID antennas; their properties, how to apply them, their performance, benefits and drawbacks and future developments for these inks. In addition, some attention will be given to adhesives, which are necessary to bond the die or die strap to the antenna.

Conductive inks have their place in the HF-RFID market, with proven performance in the field. But, the UHF-RFID market is a relatively new application for inks and, while much testing has been conducted, the technology is still in its infancy.

Using conductive inks for printing RFID antennas has several benefits: printing is an additive process and generates much less waste than certain subtractive processes, investment in the technology is minimal (especially for companies that are already active in the printing industry), and inks are relatively environmentally friendly. Certain inks do contain solvents, but the quantities are limited and, if one chooses not to use solventcontaining inks, there are water-based and UV-curable inks available, which are environmentally friendly.

One may think that the RF-performance of an ink is inferior to that of aluminum or copper, but experiments have proven that the opposite is true. Ink performance in RFID applications has been studied extensively and the general consensus is that inks perform as well as copper or aluminum.

\section{Theoretical background}

\subsection{Skin depth}

To evaluate the use of various materials for RFID applications, it is important to understand the basic function and historical background of RFID technology. RF radiation generates an AC current in conductive antennas. These AC currents tend to flow on the outside of an antenna and this is called the "skin effect", see Figure 1. This skin effect increases at higher frequencies, in this case the radiation goes even more to the outside and the skin depth decreases. The skin depth is the thickness of the outer layer of the material, which transfers $63 \%$ of the RF signal. This skin depth is determined by the permittivity and the conductivity of the antenna material. Since most antenna materials have a permittivity of 1 , the conductivity is the most important variable.

Source: Radio Frequency Identification Fundamentals and Applications, Design Methods and Solutions, Book edited by: Cristina Turcu, ISBN 978-953-7619-72-5, pp. 324, February 2010, INTECH, Croatia, downloaded from SCIYO.COM 


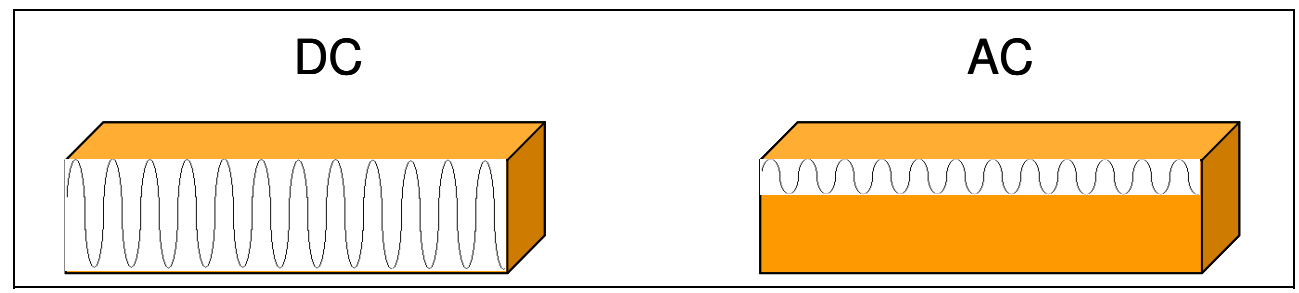

Fig. 1. Skin effect with AC-currents

A more conductive material will have a thinner skin depth. In other words, the radio waves are transferred by less material. For a less conductive material, the skin depth is thicker. Ideally, for an antenna to work properly, $100 \%$ of the radiation should be transferred. As a rule of thumb, the antenna should be around three to five times the thickness of the skin depth so that it can transport all the RF-radiation.

A comparison of the RF-performance between different antenna materials was done in (Syed et al., 2007) and (Nikitin et al., 2005). Bulk copper $(18 \mu \mathrm{m})$, thin deposited copper $(2$ $\mu \mathrm{m})$, bulk aluminum $(10 \mu \mathrm{m})$ and two conductive inks $(5$ and $8 \mu \mathrm{m})$ were compared with each other. Despite the fact that the conductivity of the silver ink was roughly ten times less conductive than the bulk copper, the performance of the inks was consistently $80-99 \%$ of the performance of the bulk copper antenna. Since conductive inks are less conductive than bulk copper or bulk aluminum, the skin depth is also larger. As mentioned in (Syed et al., 2007) the skin depth for the ink, at $915 \mathrm{MHz}$, is in the 7-8 micron range, while bulk copper has a skin depth of 2.18 micron. By printing a thicker layer of the ink, this difference can be overcome. Results in (Nikitin et al. 2005) indicate that, for certain antenna designs, a silver ink antenna performs as well as a copper antenna for HF-RFID. For lower frequencies, the skin depth is higher and thicker layers must be printed.

\subsection{Electrically conductive inks}

Electrically conductive inks are used in a wide variety of applications. The conductive tracks in printed circuit boards are a mature and well-known application. Other examples are membrane touch switches, heating elements, sensors and displays. RFID and medical applications are more recent and emerging, while photovoltaics and printed transistors present future opportunities for electrically conductive ink applications.

Simply put, a conductive ink consists of a polymer, a solvent, a pigment and additives. The

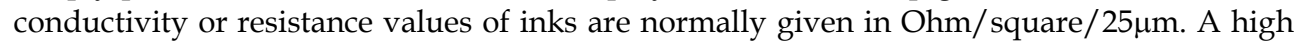
conductive ink has a low resistance.

The polymer or binder will keep the pigment particles together and determine the mechanical properties - such as adhesion, flexibility and hardness of the final ink. To make the ink processable, the binder is dissolved. Application technique determines which solvent is used. For a typical application method such as screen printing, high boiling point solvents are used. High-speed printing methods like rotogravure, require low boiling point solvents. Most important is the pigment, as it determines the conductivity of the final ink. Most of today's materials employ silver as the pigment. Usually the silvers are flake- type materials, as these tend to provide the highest conductivity (Figure 2). Characteristics like the surface area, particle size and the type of lubricant have great influence on the final conductivity of the dried ink. 


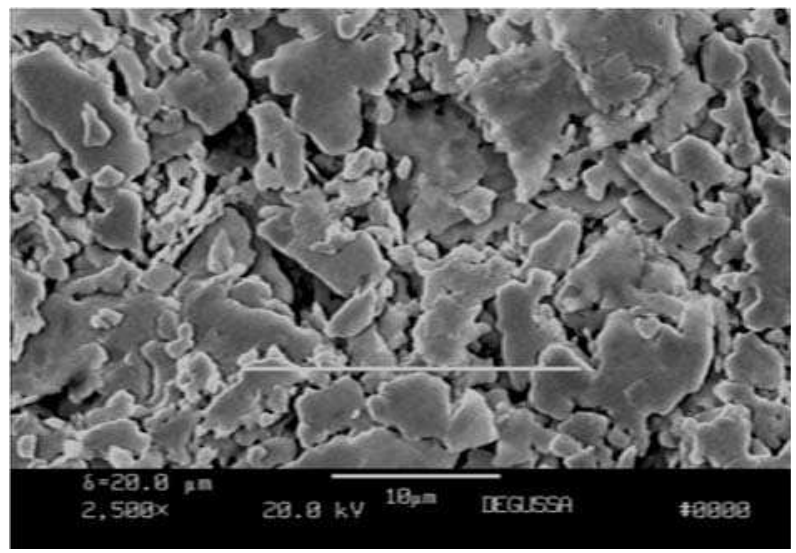

Fig. 2. An example of silver flake (source: Website www.Ferro.com)

In order to optimize the properties of the ink, several additives can be used in a formulation. These can improve wetting, flow, adhesion, flexibility or the rheology of the ink. Some additives can be used to promote the conductivity.

\section{Application methods}

Application methods are of key consideration for RFID inks and it is, therefore, important to understand the primary printing techniques, which include screen printing, flexography and rotogravure. Screen printing is very well-known application method for conductive inks. Flexography and rotogravure are relatively new for RFID, but very established in the packaging industry.

Table 1 below illustrates some typical values of the different printing techniques

\begin{tabular}{|l|c|c|c|}
\hline & Flexography & Rotogravure & Screen printing \\
\hline Cost & $\begin{array}{c}\text { Relatively } \\
\text { inexpensive }\end{array}$ & $\begin{array}{c}\text { Requires long runs to be } \\
\text { cost effective }\end{array}$ & $\begin{array}{c}\text { Relatively } \\
\text { Inexpensive }\end{array}$ \\
\hline Speed & $15->150 \mathrm{mpm}$ & $30->400 \mathrm{mpm}$ & $3-60 \mathrm{mpm}$ \\
\hline Print quality & Good & Excellent & Excellent \\
\hline Print thickness & $2-5 \mu \mathrm{m}$ & $2-5 \mu \mathrm{m}$ & $5-25 \mu \mathrm{m}$ \\
\hline $\begin{array}{l}\text { Boiling point } \\
\text { range solvents }\end{array}$ & $80-140^{\circ} \mathrm{C}$ & $80-140^{\circ} \mathrm{C}$ & $130-210^{\circ} \mathrm{C}$ \\
\hline
\end{tabular}

Table 1. Comparison printing techniques

The printing technology selected will have a large impact on the process speed for RFID tags.

\subsection{Screen printing}

Screen printing is a porous printing process. Distinct from flexography and rotogravure, the image and the non-image are in the same plane. A mesh stencil carrier -- usually nylon, polyester or stainless steel -- is stretched tightly over a frame. An image is created by covering the non-image parts by an adhesive foil. Another common method is covering the 
mesh with a photopolymer and subsequently exposing the mesh to a photographic positive and polymerizing the non-image parts. After removing the un-polymerized parts, an image remains. During printing, the frame is loaded with ink and a squeegee presses the ink through the image parts of stencil and onto the substrate, see figure 3.

Screen printing is used for displays, signs, instrument panels, textiles and posters. It is a relatively slow printing process, by comparison. A totally automatic flatbed screen printing machine has an output speed around 1500 impressions per hour.

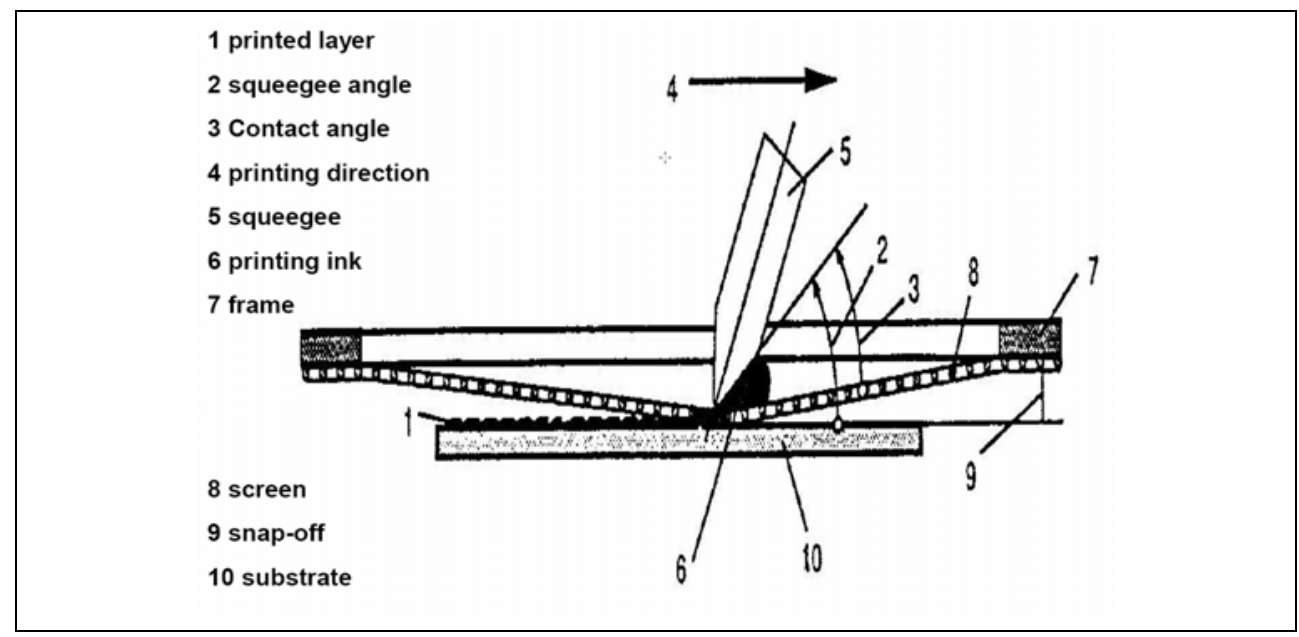

Fig. 3. Schematic figure of the screen printing process

A modification on screen printing is rotary screen printing, where an ink supply and the squeegee are fitted inside a rotary screen cylinder. This process is a competitor for flexography and gravure in both output and costs.

\subsection{Flexography}

The original name of flexographic printing was aniline printing, but the name was changed in 1952 for the following reasons:

- Flexible and elastomeric printing plates were used

- It was the most widely used technique for printing flexible materials

- The process is flexible and enables printing of flexible, non-flexible, rigid materials

- The process may be used for applications other than printing (coating, sizing and laminating, for example)

Flexography is used in a wide variety of printing in packaging, publication, business, and consumer products. Flexographic printing usually starts with a fountain roller which takes ink from a container. Subsequently, ink is transferred to the anilox roll. In this step, the transferred amount is controlled by the pressure of the doctor blades. The anilox roller delivers the ink to the image plate, usually a soft rubber or a photopolymer, which transfers it to the substrate (figure 4).

The anilox roller is the most important part of the flexographic printing system. It is engraved with tiny, uniform cells and transfers the ink with a precise thickness to the printing plate. Cell volume and the number of cells per inch are important features of the roller (figure 5). Figure 6 illustrates typical data of an anilox roller. 


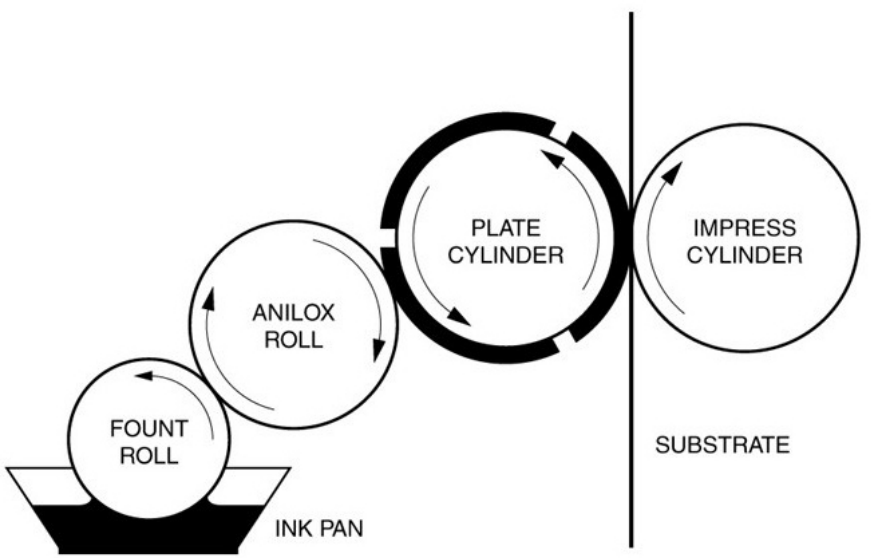

Fig. 4. Schematic representation of a flexographic press
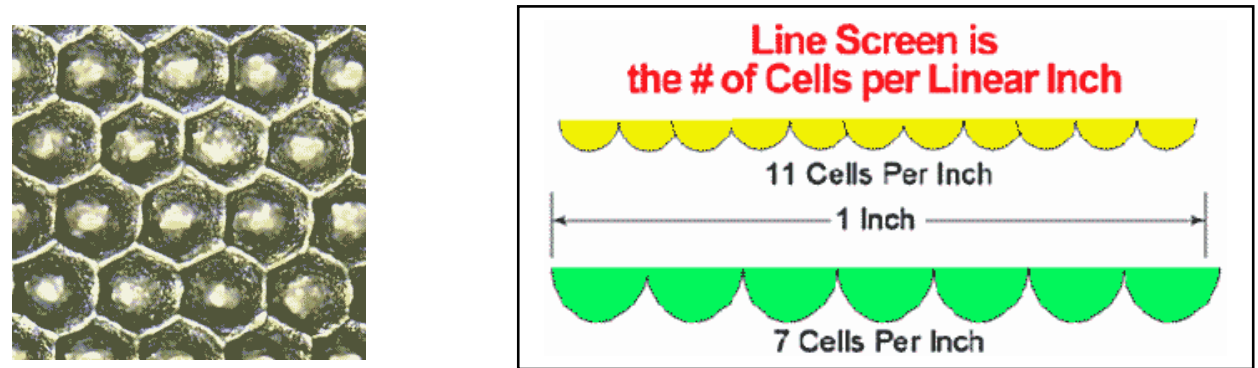

Fig. 5. Typical anilox shape and schematic of lines/inch (Figure Courtesy of Harper Corporation of America)

\begin{tabular}{|c|c|}
\hline \multicolumn{2}{|c|}{ Echochek ${ }^{m}$ Summary: } \\
\hline Line Screen: & $\begin{array}{l}800 \text { Lines per inch } \\
315 \text { Lines per cm }\end{array}$ \\
\hline Angle: & 60 degree \\
\hline Depth: & 9 microns \\
\hline C ell Opening: & 28.8 micrors \\
\hline Cell 'víall: & 3 microns \\
\hline Volume: & $\begin{array}{l}2.2 \mathrm{BCM} \\
3.4 \mathrm{~cm}^{3} / \mathrm{m}^{2}\end{array}$ \\
\hline \multicolumn{2}{|c|}{$\begin{array}{l}\text { This is a high quality engraving. The cell walk are thin } \\
\text { and corsistent, the cels are of consistent size and } \\
\text { shape, there are no high posts and the depth to opening } \\
\text { ratio is betrueen } 23 \% \text { and } 33 \% \text {. }\end{array}$} \\
\hline
\end{tabular}

Fig. 6. Typical parameters anilox roller (Figure Courtesy of Harper Corporation of America) 
In order to maintain good printing properties, most flexographic presses are equipped with an automatic viscosity control system. When necessary, the viscosity can be adjusted.

\subsection{Rotogravure printing}

Rotogravure printing is a form of intaglio printing (figure 7). The print is recessed in a metal plate or cylinder in the form of discrete cells. These printing cylinders are usually made of copper which are chromium plated for protection and comparable to the anilox roller used in flexography. During rotating of the cylinder, ink is transferred from a container to the cells of the printing plate and subsequently applied to the substrate. A doctor blade removes the excess ink. The amount of ink transferred depends on the depth of the cells.

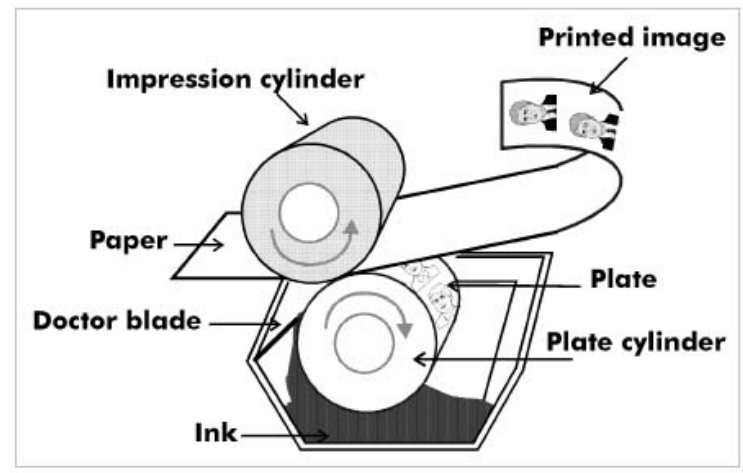

Fig. 7. Schematic representation of a rotogravure printer

Gravure printing is used for publication and package printing and delivers high-quality output at high speeds. Publication printing is undertaken on very expensive, custom made, presses. The cylinders usually contain eight A4 pages and print approximately 35000 impressions per hour.

Package printing by gravure is managed on standard-sized machines, but with a wide variety of cylinder widths to suit the product. Speeds of 300 meters per minute are normal. The cylinders are stored for reprinting. This requires additional space and increases the production costs.

\section{Rheology (Rheology and drying of RIFD ink)}

\subsection{Rheology}

To make the RFID antenna, inks are applied by one of the different techniques noted previously. In order to print effectively, the inks require a certain rheology. Rheology characterizes the deformation and flow of a material. An ink must have the proper deformation and flow properties to be applicable by certain printing techniques.

Screen-printable inks are usually high viscous pastes. They must stay on the screen, but once a force is applied, they should thin down and flow through the screen. Once pressed through the screen, the materials cannot flow out, but must remain in place in order to achieve line definition (Hoornstra et al., 1997).

Figure 8 illustrates the different stages during the screen printing process and some typical viscosity values of screen inks during these stages. 
The same is done for the flexo and gravure processes in (Geiger \& Henderson, 2001). This is schematically shown in figure 9.

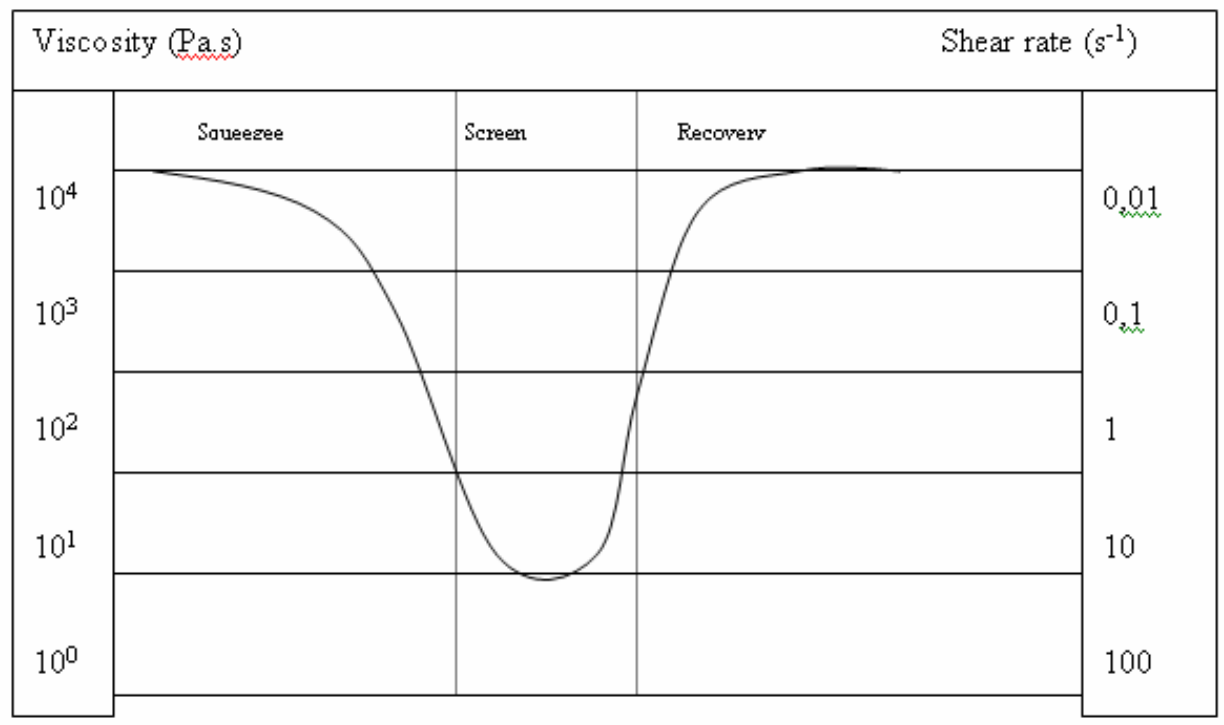

Fig. 8. Typical shear rates and viscosities during the screen print process

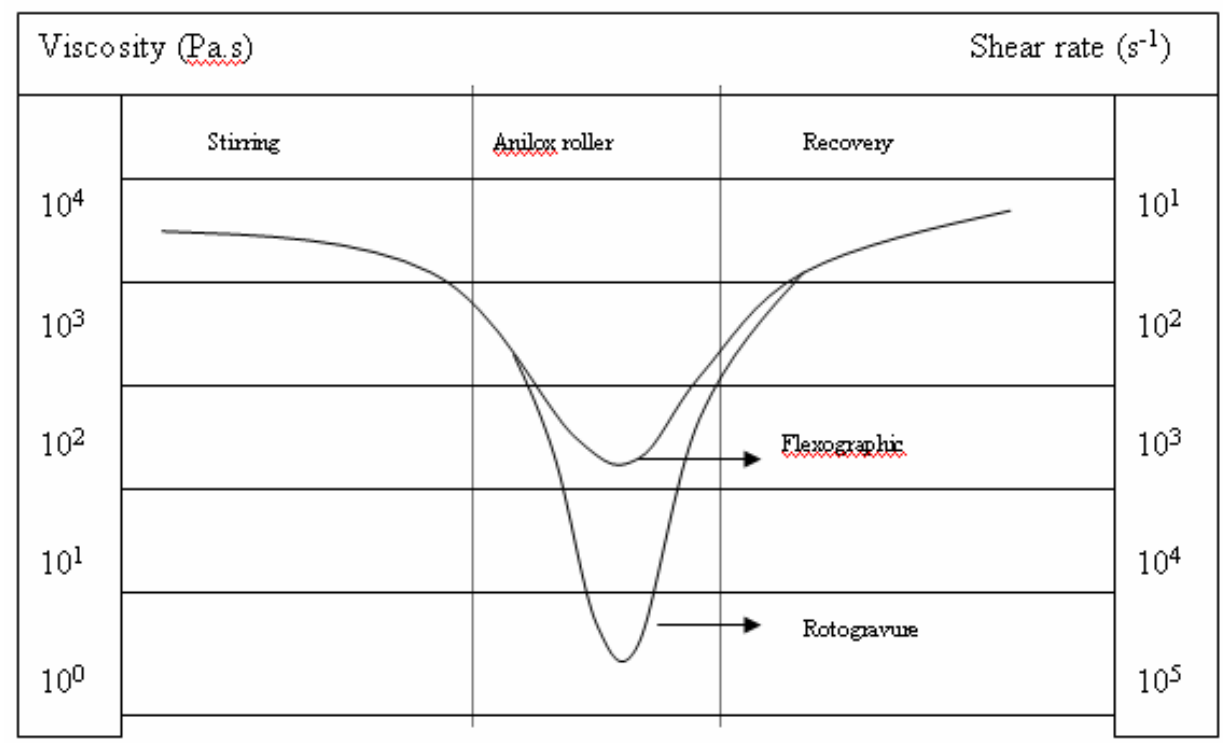

Fig. 9. Typical shear rates and viscosities during flexo and gravure process

There are differences in flexo printable graphical inks and conductive inks. A closer look at a graphical print shows the typical "dot" structure, as seen in figure 10. Usually relatively low 
volume anilox types are used for this application and, in this case, all dots are not connected, but different colors are printed on top of each other to yield the desired color. If the same anilox volumes were used for conductive inks, the printed structure would most likely not be conductive. For conductive inks, higher cell volumes are used to create a conductive trace. Figure 11 shows the influence of the cell volume on the trace morphology.

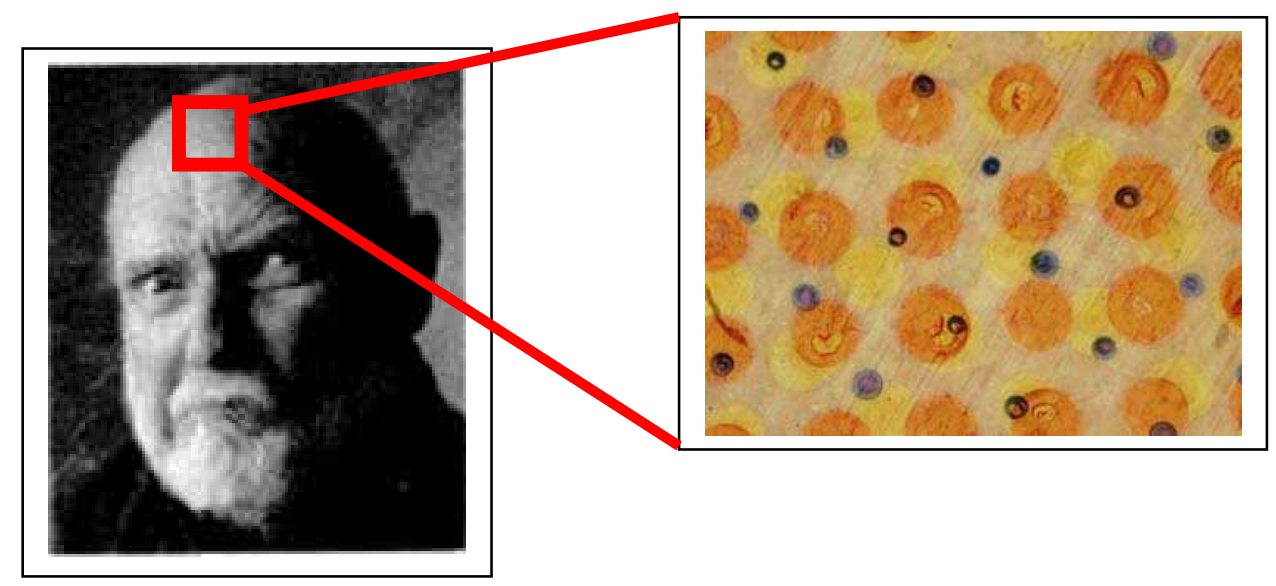

Fig. 10. A flexo printed bold face and its magnification.

The figure below shows the influence of the cell volume of a flexo printed conductive ink.

High cell volume

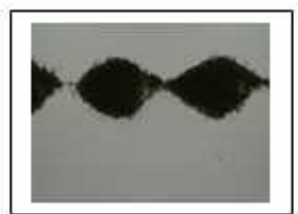

Lower cell volume

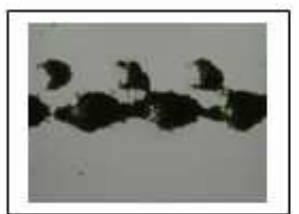

Lowest cell volume

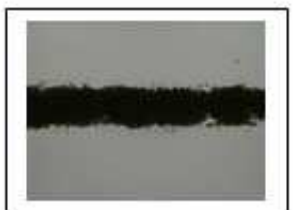

Fig. 11. Influence cell volume

Drying

Another critical step in the RFID antenna print process is the drying of the ink, as it determines the final properties of the antenna. When drying is not sufficient, the conductivity will be too low and some of the mechanical properties may fail.

Drying can be achieved with conveyer ovens, box ovens, hot air, infrared heaters or contact driers. Of great importance are the printing speed and the applied layer thickness, as they have a significant influence on the amount of heat required to completely dry the ink.

\section{Typical properties and RF-performance}

The properties of RFID inks can be divided into wet and dry properties and, of course, the RF-performance. The key parameter is the conductivity or resistance of the dried ink. After the ink is dried, conductivity is normally the first characteristic that is examined. Other important properties are the adhesion/cohesion and flexibility of the inks. 
To determine the conductivity or the resistance of the dried ink, the resistance over a track of known dimensions is measured. To compensate for differences in layer thickness, the value is normalized to a thickness of $25 \mu \mathrm{m}$. Figure 12 shows how the resistance value is determined.

$$
\begin{aligned}
& \mathbf{R p}(\Omega / \mathbf{s q} . / \mu \mathbf{m})=\frac{\mathbf{R} \mathbf{t} \times \mathbf{t} \times \mathbf{W}}{25 \times \mathbf{L}} \text { or } \mathbf{R t}=\frac{\mathbf{R p} \times \mathbf{L} \times \mathbf{c}}{25 \times \mathbf{W}} \\
& \mathrm{Rp}=\text { product resistance }(\text { ohm } / \mathrm{sq} . / 25 \mu \mathrm{m}) \\
& \mathrm{Rt}=\text { track resistance }(\text { ohm }) \\
& \mathrm{t}=\text { dry coating thickness }(\mu \mathrm{m}) \\
& \mathrm{W}=\text { track width }(\mathrm{mm}) \\
& \mathrm{L}=\text { track length }(\mathrm{mm})
\end{aligned}
$$

Fig. 12. Resistance calculation

Because of the roughness of certain printed inks, it is sometimes difficult to determine the exact layer thickness. When this is the case, the resistance is determined in Ohm/square.

Another important property is the adhesion of the ink to various substrates and there are several ways to measure adhesion. One of the most common methods is ASTM-3359B, as illustrated in figure 12. Using a special device, squares are cut in the ink following which a special tape is put on the ink and removed. The removed quantity of ink determines the measure for its adhesion, rated as in figure 13.

\begin{tabular}{|c|c|}
\hline Rating & $\begin{array}{l}\text { Appearance of the crosscut } \\
\text { after adhesion test }\end{array}$ \\
\hline 5B & no removal \\
\hline 4B & \\
\hline 3B & \\
\hline 2B & \\
\hline 1B & \\
\hline 0B & More than $65 \%$ removal \\
\hline
\end{tabular}

\section{Rating}

5B: no removal

4B: $<5 \%$ removed

3B: $5-15 \%$ removed

$2 B: 15-35 \%$ removed

1B: $35-65 \%$ removed

OB: $>65 \%$ removed

Fig. 13. Adhesion test ASTM-3359B

RFID tags can be used in a variety of environments and, to ensure the antenna maintains its performance, the resistance should remain consistent regardless of varying environmental 
conditions. Using a chamber which is $85^{\circ} \mathrm{C}$ and has a relative humidity of $85 \%$, harsh conditions can be simulated. The resistance of a defined track of dried ink is measured and put in the 85/85 chamber. After a set period of time, the percentage of change in resistance is measured to determine the environmental stability of the ink.

Table 2 illustrates s some typical properties of inks used for RFID applications.

\begin{tabular}{|c|c|c|c|c|c|}
\hline Type of ink & & Solvent & Solvent & Water & Solvent \\
\hline RFID Segment & & $\mathrm{HF}$ & UHF & UHF & Plating* \\
\hline Application & & Screen & Flexo & Flexo & Gravure \\
\hline Wet properties & unit & & & & \\
\hline Solids & $\%$ & 68 & 60 & 83 & 72 \\
\hline Density & $\mathrm{kg} / \mathrm{m}^{3}$ & 2390 & 1920 & 3200 & 2340 \\
\hline Viscosity & mPa.s & 17500 & 2000 & 4000 & 4400 \\
\hline Storage Temp & ${ }^{\circ} \mathrm{C}$ & $<25^{\circ} \mathrm{C}$ & $<35^{\circ} \mathrm{C}$ & $<35^{\circ} \mathrm{C}$ & $<35^{\circ} \mathrm{C}$ \\
\hline Shelf life & Months & 12 & 12 & 12 & 12 \\
\hline \multicolumn{6}{|l|}{ Dry properties } \\
\hline Sheet resistance & Ohm/sq/mil & $<0.010$ & $<0.015$ & $<0.035$ & $<0.010$ \\
\hline Adhesion & & $5 \mathrm{~B}$ & $5 \mathrm{~B}$ & $5 \mathrm{~B}$ & $5 \mathrm{~B}$ \\
\hline Cohesion & & No failure & No failure & No failure & No failure \\
\hline Stability $85 / 85$ & & No change & No change & No change & No change \\
\hline Reading distance & $\mathrm{m}$ & $<0.10$ & $\sim 3$ & $\sim 3$ & NA \\
\hline & & & & & \\
\hline The use of a plat & ink is a nev & and $\operatorname{cost} \epsilon$ & ctive techr & ue to make & \\
\hline
\end{tabular}

Table 2. Some typical wet and dry ink properties

Ultimately, the success of an RFID antenna is determined by its reading performance which, of course, depends on more than only the ink.

Table 3 provides some reading distances of a UHF ink. The printing, drying and die bonding, were conducted under the same circumstances. In this instance, although there is a wide spread in conductivity caused by the substrate, there is no clear influence on the reading performance. This indicates that conductivity is important, but not the only factor that influences the reading performance.

\begin{tabular}{|c|c|c|c|c|c|c|}
\hline & & speed & anilox & anilox & Shorted $\mathrm{R}$ & read distance \\
\hline Ink & Substrate & $\mathrm{m} / \mathrm{min}$ & $\mathrm{ml} / \mathrm{m} 2$ & $\mathrm{~L} / \mathrm{cm}$ & $($ Ohm $)$ & $\mathrm{m}$ \\
\hline $17 \mu \mathrm{m} \mathrm{Cu}$ & PET & & & & 0.4 & 3.1 \\
\hline UHF ink & M-Cote & 37 & 18.5 & 55 & 31.1 & 2.6 \\
\hline UHF ink & Fasson PP & 37 & 18.5 & 55 & 25.9 & 2.5 \\
\hline UHF ink & Transfer matt & 37 & 18.5 & 55 & 21 & 2.6 \\
\hline UHF ink & Cast-Cote & 37 & 18.5 & 55 & 17.6 & 2.6 \\
\hline UHF ink & Algro Finess 2000 & 35 & 18.5 & 55 & 15.7 & 2.7 \\
\hline
\end{tabular}

Table 3. Reading distance of a dried UHF ink, printed on different substrates and compared to $17 \mu \mathrm{m}$ copper. 


\section{The plating approach}

A relatively new technology is the production of an HF-antenna by using copper plating technology. Figure 14 illustrates the plating process steps.

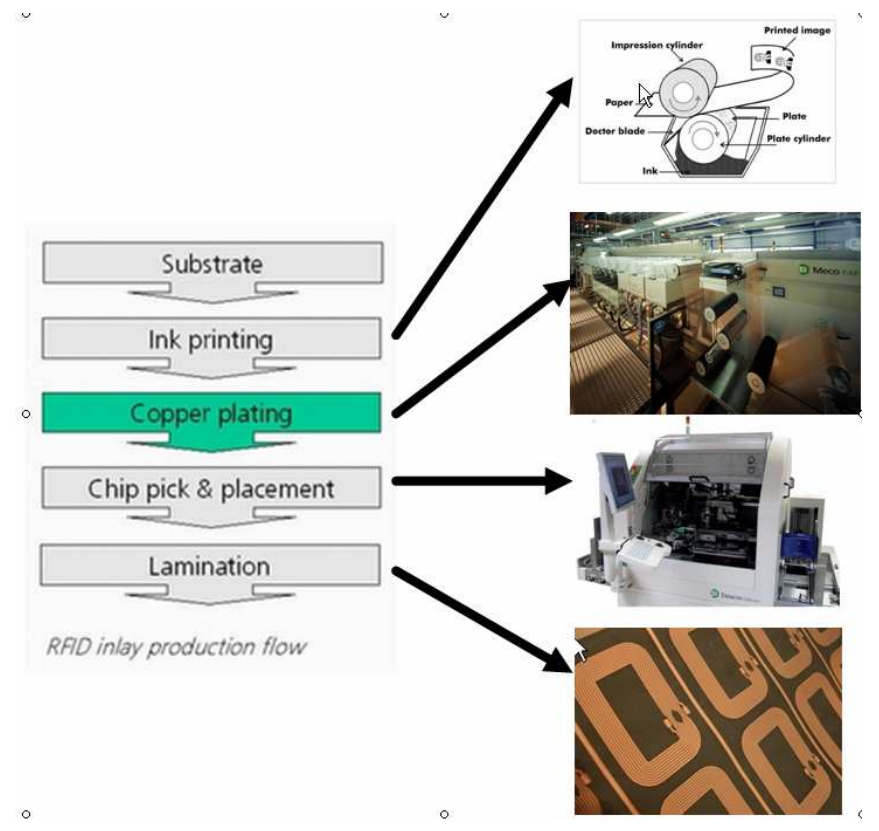

Fig. 14. Different steps of the plating process

A very thin plating or receptor ink is applied first. This can be achieved with different printing techniques, but rotogravure is probably the most cost-effective and efficient method. After drying/curing the ink, copper is electrochemically deposited onto the plating ink.

To be able to plate the ink with copper, certain conductivity is required. Since the printed layer is very thin -- only $2-4 \mu \mathrm{m}$-- it is critical that the plating ink is rather conductive. The ink should dry quickly and have high peel strength to ensure good antenna to substrate adhesion.

\section{Conductive adhesives}

Although adhesives are different from inks, the basic elements are similar. Conductive adhesives usually perform very well in combination with inks, therefore they are briefly discussed here.

After the antenna is printed, the die or die-strap (figure 15) is attached. For die strap attach, Isotropic Conductive Pastes (ICPs), which are conductive in the $\mathrm{X}, \mathrm{Y}$, and $\mathrm{Z}$ direction, are used. For direct die attach, Anisotropic Conductive Pastes (ACPs) can be used and, for this application, only conductivity in the Z-direction in needed. In some cases, the bare die contains spikes which will connect with the antenna material. A non-conductive adhesive paste (NCP) can be applied to keep the die in place. 


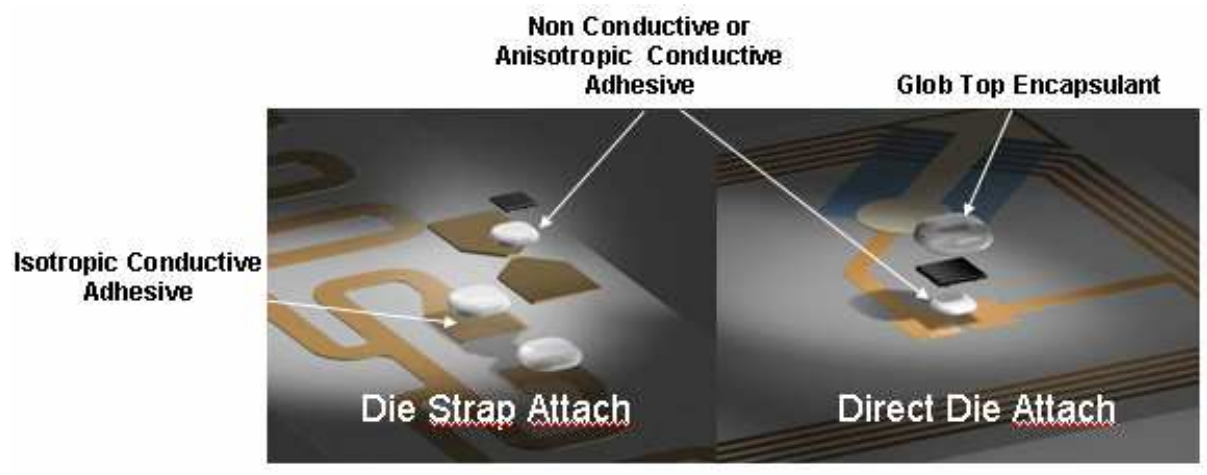

Fig. 15. Die strap and direct die attach

Common application methods of die attachment are jet dispensing and screen printing. The curing of the adhesives should be quick, and process speed is dictated by the printing method used.

Some other key properties are shown in table 4.

\begin{tabular}{|c|c|c|c|}
\hline Property & Test Method & $\begin{array}{l}\text { Positive } \\
\text { Control }\end{array}$ & $\begin{array}{l}\text { Negative } \\
\text { Control }\end{array}$ \\
\hline $\begin{array}{c}\text { Cure }<10 \text { s at } \\
<130^{\circ} \mathrm{C}\end{array}$ & hot plate & Cure $<10 \mathrm{~s}$ & Cure $>10 \mathrm{~s}$ \\
\hline $\begin{array}{l}\text { Initial contact } \\
\text { resistance }\end{array}$ & $\begin{array}{l}\text { DC resistance measured } \\
\text { on shorted } \mathrm{vd} \mathrm{Cu} \text { strap } \\
\text { bonded to stamped } \mathrm{AI} \\
\text { trace on } \mathrm{PET}\end{array}$ & $\begin{array}{l}\text { Initial contact } \\
\text { resistance }<1 \text { Ohm } \\
\text { across strap }\end{array}$ & $\begin{array}{c}\text { Initial contact resistance } \\
>1 \mathrm{Ohm} \text { across strap }\end{array}$ \\
\hline $\begin{array}{c}\text { Contact resistance } \\
\text { stability after } 2 \\
\text { weeks } 85 \text { 'C/85\% } \\
\text { RH }\end{array}$ & $\begin{array}{l}\text { DC resistance measured } \\
\text { on shorted } v d \mathrm{Cu} \text { strap } \\
\text { bonded to stamped } \mathrm{AI} \\
\text { trace on PET }\end{array}$ & $\begin{array}{c}\text { Contact resistance }<1 \\
\text { Ohm across strap after } \\
\text { conditioning }\end{array}$ & $\begin{array}{c}\text { Contact resistance }>1 \\
\text { Ohm across strap after } \\
\text { conditioning }\end{array}$ \\
\hline Jettability & $\begin{array}{c}\text { Asymtek jet dispenser - } \\
\text { dotshour }\end{array}$ & $\begin{array}{c}=40,000 \text { dotsihour with } \\
\text { no skipped dots }\end{array}$ & $\begin{array}{c}<10,000 \text { dots' hour with } \\
\text { skipped dots }\end{array}$ \\
\hline $\begin{array}{c}\text { Good mechanical } \\
\text { strength }\end{array}$ & $\begin{array}{l}\text { Bend test on } 3 / 4 \text { " diameter } \\
\text { mandrel; } 20 \text { bends face } \\
\text { up, } 20 \text { face down }\end{array}$ & $\begin{array}{c}15 \% \text { change in } \\
\text { contact resistance from } \\
\text { initial }\end{array}$ & $\begin{array}{l}>15 \% \text { change in contact } \\
\text { resistance from initial }\end{array}$ \\
\hline Good work life & $\begin{array}{c}\text { Viscosity change at room } \\
\text { temperatue }\end{array}$ & $\begin{array}{l}=25 \% \text { change from } \\
\text { initial }\end{array}$ & $=25 \%$ change from initial \\
\hline
\end{tabular}

Table 4. General RFID adhesive properties

Because antennae can be made of silver, aluminum and copper, there are also different adhesives available. 


\section{New developments}

Future developments in RFID ink technology are focused on cost efficiency, the environment and improving conductivity.

To address the needs of the low-cost RFID market, manufacturing inks using less silver would be extremely beneficial. Many years ago the silver price was rather steady, but in recent years, silver prices have had large fluctuations, which have had a tremendous impact on ink pricing. Reducing the silver content would help stabilize pricing.

Environmental responsibility also plays an important role in materials development. Reducing the halogen content as well as the amount of solvent used are efforts that are underway to ensure the environmental friendliness of modern RFID materials.

However, many of these environmentally friendly systems generally exhibit lower conductivity values than conventional systems. New and non traditional pigments are needed to accommodate these issues.

Silver-coated copper - a method by which copper base pigments are covered with a very thin layer of silver -- is currently one of the most studied materials. Although silver-coated coppers are not new to the market, those previously developed have not been suitable for printing inks.

Recently, however, more suppliers of silver-coated copper have entered the market, resulting in rapid improvements to the properties of these materials.

Water-based systems are available for UHF RFID and environmentally appealing because they do not contain harmful solvents, yet provide good conductivity at room temperature.

Several experiments have been done with water-based systems on a wide variety of substrates, and results suggest that these systems work well with numerous substrates. One drawback to water-based inks is that they do tend to dry quickly under certain conditions. If the ink dries on the flexo plate, it may prevent subsequent printing. However, good viscosity control and an enclosed doctor blade system may eliminate these issues.

With current materials, there remains a gap between the conductivity values of water-based inks and conventional, solvent-based inks. Water-based systems reach conductivities in the $20 \mathrm{mOhm} / \mathrm{sq} / \mathrm{mil}$ range, whereas solvent-based systems can reach conductivities of less than $10 \mathrm{mOhm} / \mathrm{sq} / \mathrm{mil}$. New developments are aiming to narrow this gap, while also achieving more cost-effective pigments.

UV-curable systems provide many benefits, not the least of which is their user familiarity, friendliness for RFID applications. Flexo printers are very amenable to this technology, as the ink will not dry on the flexo plate and can be left exposed to air for some time without any adverse effects. . Because there are little to no solvents in these systems, coverage is very high and environmental emissions are limited. Table 5 gives illustrates results of an experimental UV-curable UHF ink as compared to a water-based UHF ink; both deliver the same RF-performance.

UV-curable conductive inks have high silver loading to create conductivity. Because of this, a relatively high amount of UV-energy is needed to fully cure the material. This can be mitigated, however, by an additional heat exposure, either through hot air or infrared, will overcome some of this and promote curing to yield better conductivity development.

Like water-based conductive technologies, the conductivity of UV-curable inks has not yet reached the level of conventional solvent-based systems. Efforts are ongoing to increase these conductivity levels, while also improving cost-effectiveness of these systems. 


\begin{tabular}{|c|c|c|c|c|}
\hline & & Shorted R & Heat treat & Read distance \\
\hline Ink & Substrate & $($ Ohm $)$ & $($ Ohm $)$ & $\mathrm{m}$ \\
\hline $17 \mu \mathrm{m} \mathrm{Cu}$ & PET & 0.4 & & 3.1 \\
\hline water & Algro Finess 2000 & 25.8 & 15.7 & 2.7 \\
\hline water & Algro Finess 2000 & 16.2 & 9.7 & 2.7 \\
\hline UV & Algro Finess 2000 & 9.5 & 4.2 & 2.7 \\
\hline UV & Algro Finess 2000 & 19.2 & 10.5 & 2.6 \\
\hline
\end{tabular}

Table 5. Read distance water-based UHF ink versus UV-curable UHF ink

\section{Conclusion}

Conductive inks are very relevant for certain applications within the RFID market, with performance being consistent with that of aluminum or copper antennas. Printing and drying of the ink are key to manufacturing a functional antenna. RFID can be very costeffective for existing print houses, as no additional investment is required for market entry. Printing is an additive process, which means less waste, and screens and flexo plates are relatively inexpensive, which enables frequent switching to other designs.

However, there are drawbacks to using inks, not the least of which is cost. Development of lower-cost inks is underway, and successful formulation would certainly encourage more widespread use in the RFID market.

\section{References}

Syed, A.; Demarest, K. \& Deavours, D.D.(2007). Effects of Antenna Material on the Performance of UHF RFID Tags. IEEE RFID, March 26-28, Grapevine, TX, p 57-62 Performance of UHF RFID Tags

Nikitin, P.V.; Lam, S. \& Rao, K.V.S. (2005). Low Cost Silver Ink RFID Tag Antennas. IEEE Antennas and Propagation Symposium, Washington.

Hoornstra J.; Weeber A. W.; de Moor H. H. C.\& Sinke W. C. (1997). The importance of paste rheology in improving fine line, thick film screen printing of front side metallization, $14^{\text {th }}$ EPSEC, Barcelona, 823-826

Geiger R. J.\& Henderson C. A. (2001) Radtech report, 15-19, July/August 2001 


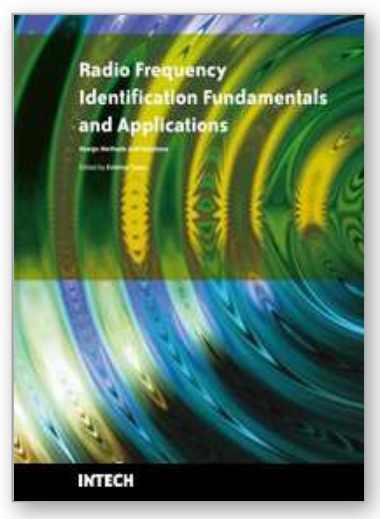

\author{
Radio Frequency Identification Fundamentals and Applications \\ Design Methods and Solutions \\ Edited by Cristina Turcu
}

ISBN 978-953-7619-72-5

Hard cover, 324 pages

Publisher InTech

Published online 01, February, 2010

Published in print edition February, 2010

This book, entitled Radio Frequency Identification Fundamentals and Applications, Bringing Research to Practice, bridges the gap between theory and practice and brings together a variety of research results and practical solutions in the field of RFID. The book is a rich collection of articles written by people from all over the world: teachers, researchers, engineers, and technical people with strong background in the RFID area. Developed as a source of information on RFID technology, the book addresses a wide audience including designers for RFID systems, researchers, students and anyone who would like to learn about this field. At this point I would like to express my thanks to all scientists who were kind enough to contribute to the success of this project by presenting numerous technical studies and research results. However, we couldn't have published this book without the effort of InTech team. I wish to extend my most sincere gratitude to InTech publishing house for continuing to publish new, interesting and valuable books for all of us.

\title{
How to reference
}

In order to correctly reference this scholarly work, feel free to copy and paste the following:

Rudie Oldenzijl, Gregory Gaitens and Douglass Dixon (2010). Conduct Radio Frequencies with Inks, Radio Frequency Identification Fundamentals and Applications Design Methods and Solutions, Cristina Turcu (Ed.), ISBN: 978-953-7619-72-5, InTech, Available from: http://www.intechopen.com/books/radio-frequencyidentification-fundamentals-and-applications-design-methods-and-solutions/conduct-radio-frequencies-withinks

\section{INTECH}

open science | open minds

\section{InTech Europe}

University Campus STeP Ri

Slavka Krautzeka 83/A

51000 Rijeka, Croatia

Phone: +385 (51) 770447

Fax: +385 (51) 686166

www.intechopen.com

\section{InTech China}

Unit 405, Office Block, Hotel Equatorial Shanghai

No.65, Yan An Road (West), Shanghai, 200040, China

中国上海市延安西路65号上海国际贵都大饭店办公楼 405 单元

Phone: +86-21-62489820

Fax: $+86-21-62489821$ 
(C) 2010 The Author(s). Licensee IntechOpen. This chapter is distributed under the terms of the Creative Commons Attribution-NonCommercialShareAlike-3.0 License, which permits use, distribution and reproduction for non-commercial purposes, provided the original is properly cited and derivative works building on this content are distributed under the same license. 